\title{
STRATEGI BUDIDAYA IKAN PATIN (PENGASIUS SP) UNTUK MENINGKATKAN PENDAPATAN KELOMPOK TANI IKAN MINA KENCANA DESA PERING KECAMATAN BLAHBATUH
}

\author{
B.R.T. Putri ${ }^{1}$, N.L.G. Sumardani ${ }^{2}$, I.D.P. Singarsa ${ }^{3}$ dan N.N. Yastini ${ }^{4}$
}

\begin{abstract}
ABSTRAK
Desa pering merupakan salah satu desa penghasil ikan air tawar di Bali. Ikan patin (Pangasius sp.) merupakan salah satu komoditas ikan air tawar yang banyak dibudidayakan di Desa Pering. Tujuan penelitian ini adalah: 1) menganalisis kondisi usaha budidaya ikan patin, 2) menganalisis kondisi internal dan eksternal usaha peternakan ikan patin, 3) menganalisis posisi usaha peternakan ikan patin di dalam industri peternakan ikan air tawar, dan 4) merekomendasikan strategi usaha yang tepat untuk meningkatkan pendapatan petani. Data penelitian ini dianalisis menggunakan analisis internal-eksternal, analisis SWOT, analisis QSPM, dan analisis deskriptif. Hasil penelitian menunjukkan bahwa usaha peternakan ikan patin berada pada sel ke V pada matriks IE dengan total skor internal 2,05 dan total skor eksternal 2,95. Terdapat lima alternatif strategi yang ditawarkan untuk meningkatkan pendapatan petani, yaitu: 1) melakukan integrasi usaha dari hulu hingga ke hilir, 2) melakukan segmentasi pasar, 3) mengadakan kerjasama dengan berbagai pihak dalam memasarkan patin dan produk olahannya, 4) memanfaatkan media online untuk promosi dan pemasaran produk, dan 5) melakukan diversifikasi produk menjadi berbagai produk olahan lainnya. Prioritas strategi yang ditawarkan adalah melakukan integrasi usaha dari hulu hingga ke hilir.
\end{abstract}

Kata kunci : internal-eksternal, SWOT, QSPM, alternatif strategi, prioritas strategi.

\begin{abstract}
Pering village is one of the villages producing freshwater fish in Bali. Catfish (Pangasius sp.) Is a freshwater fish commodity that is widely cultivated in Pering Village. The objectives of this study are: 1) analyzing the conditions of catfish culture, 2) analyzing internal and external conditions of catfish farming, 3) analyzing the position of catfish farming in the freshwater fish farming industry, and 4) recommending the right business strategy to increase farmers' incomes. The data of this study were analyzed using internal-external analysis, SWOT analysis, QSPM analysis, and descriptive analysis. The results showed that the catfish farming business was in cell $\mathrm{V}$ in the IE matrix with a total internal score of 2.05 and a total external score of 2.95. There are 5 alternative strategies offered to increase farmers' income, namely: 1) integrating businesses from upstream to downstream, 2) segmenting the market, 3) collaborating with various parties in marketing patin and its processed products, 4) utilizing online media to product promotion and marketing, and 5) diversifying products into various other processed products. The priority strategy offered is to do business integration from upstream to downstream.
\end{abstract}

Keywords: internal-external, SWOT, QSPM, alternative strategies, priority strategies.

\footnotetext{
${ }^{1}$ Fakultas Peternakan Universitas Udayana, tanamaputri@unud.ac.id

${ }^{2}$ Program Studi Peternakan Fakultas Peternakan Universitas Udayana, nlg_sumardani@ unud.ac.id

${ }^{3}$ Program Studi Agroekoteknologi Fakultas Pertanian Universitas Udayana, dewasingarsa@unud.ac.id

${ }^{4}$ Program Studi Pertanian Elektro Fakultas Pertanian Universitas Dwijendra
} 


\section{PENDAHULUAN}

Sektor perikanan memiliki peranan penting dalam perekonomian masyarakat di Kecamatan Blahbatuh, baik dalam memenuhi kebutuhan pangan dan gizi masyarakat, sebagai penyedia bahan baku industri, memperluas lapangan kerja dan peluang berusaha, serta mendukung pembangunan wilayah. Saat ini, Kecamatan Blahbatuh merupakan wilayah penghasil ikan air tawar terbesar di Kabupaten Gianyar dengan jumlah produksi sebanyak 279.020 ton/tahun (BPS Kabupaten Gianyar, 2018). Usaha budidaya ikan air tawar yang berkembang di Kecamatan Blahbatuh adalah budidaya ikan air tawar di kolam. Hal ini memungkinkan di lakukan dengan adanya dukungan faktor sumber daya yang tersedia di Kecamatan Blahbatuh, seperti ketersediaan air dengan kualitas baik sepanjang tahun serta pengalaman masyarakat dalam budidaya ikan air tawar. Terdapat beberapa jenis ikan yang selama ini dibudidayakan di Kecamatan Blahbatuh, diantaranya: lele, nila, dan patin (Pengasius sp.). Salah satu kelompok tani ikan yang hingga saat ini masih melakukan usaha budiaya ikan patin adalah Kelompok Tani Ikan Mina Kencana, yang berlokasi di Desa Pering.

Ikan patin (Pengasius sp.) merupakan komoditas ikan yang baru dibudidayakan di Kecamatan Blahbatuh. Ikan patin memiliki kandungan gizi tinggi, omega 3, dan rendah kolesterol sehingga baik untuk dikonsumi oleh anak-anak, maupun orang dewasa, dan manula. Namun demikian, masyarakat belum mengenal dengan baik keunggulan ikan patin dibandingkan dengan ikan air tawar lainnya, sehingga daya serap pasar terhadap ikan patin saat ini masih rendah. Selain permasalahan pemasaran, peternakan juga mengalami kendala dalam hal budidaya ikan patin baik dalam manajemen pemeliharaan, efisiensi pakan, maupun rendahnya penerapan teknologi tepat guna. Kondisi ini mengakibatkan rendahnya pertumbuhan usaha budidaya ikan patin di masyarakat.

Berdasarkan uraian tersebut, maka tujuan penelitian ini adalah : 1) menganalisis kondisi usaha budidaya ikan patin, 2) menganalisis kondisi internal dan eksternal usaha peternakan ikan patin, 3) menganalisis posisi usaha peternakan ikan patin di dalam industri peternakan ikan air tawar, dan

4) merekomendasikan strategi usaha yang tepat untuk

\section{METODE PENELITIAN}

Penelitian ini dilaksanakan dari bulan Mei sampai bulan Agustus 2019 di Kelompok Tani Ikan Mina Kencana, Desa Pering, Kecamatan Blahbatuh, Kabupaten Gianyar. Kelompok tani ikan dipilih dengan metode purposive sampling berdasarkan kriteria: 1) Merupakan kelompok tani ikan yang melakukan budidaya ikan patin, dengan pengalaman minimal dua kali periode panen, dan 2) Berada di Kecamatan Blahbatuh. Data primer diperoleh dengan cara melakukan observasi dan wawancara terhadap responden. Wawancara dilakukan secara terstruktur dengan bantuan kuesioner. Data sekunder diperoleh dengan cara penelusuran literatur yang berkaitan dengan penelitian.

Kondisi lingkungan usaha ditentukan dengan menggunakan Analisis Faktor Internal (Internal Factor Evaluation) dan Analisis Faktor Eksternal (External Factor Evaluation), sehingga diperoleh faktor-faktor Kekuatan dan Kelemahan internal perusahaan, serta Peluang dan Ancaman yang dihadapi. Masing-masing faktor diberi bobot dan rating yang menggambarkan tingkat kepentingannya. Penentuan bobot dilakukan dengan metode Paired Comparison (Kinnear and Taylor, 1996). Menurut David (2002) pemberian peringkat (rating) ditentukan berdasarkan kondisi tingkat kepentingan masing-masing faktor, dengan skala 1 ( rendah / poor ), 2 ( sedang / average), 3 ( tinggi / above average), 4 ( sangat tinggi / superior ).

Alternatif strategi ditentukan menggunakan analisis SWOT (Rangkuti 2002), yaitu membandingkan antar faktor-faktor internal dengan eksternal sehingga diperoleh alternatif strategi yang dapat memaksimalkan Strengths (kekuatan) dan Opportunities (peluang), namun secara bersamaan dapat meminimalkan Weaknesses (kelemahan) dan Threats (ancaman). 
Analisis $Q S P M$ digunakan untuk melakukan evaluasi pilihan terhadap alternatif strategi berdasarkan tingkat kemenarikan (attractiveness score) masing-masing strategi yang telah ditentukan sebelumnya. Attractiveness score $(A S)$ ditetapkan dengan cara meneliti faktor internal dan eksternal, dan bagaimana peran dari tiap faktor dalam proses pemilihan strategi yang sedang dibuat. Batasan nilai $A S$ adalah 1 = tidak menarik, 2 = agak menarik, $3=$ menarik, $4=$ sangat menarik.

\section{HASIL DAN PEMBAHASAN}

\subsection{Kondisi Usaha Budidaya Ikan Patin}

Analisis lingkungan internal usaha budidaya ikan patin merupakan identifikasi faktor-faktor kekuatan dan kelemahan. Berdasarkan hasil survai, indepth interview, dan studi literatur yang telah dilakukan, faktor-faktor tersebut dapat ditentukan, dan selanjutnya di nilai bobot dan skornya (Tabel 3.1), untuk kemudian disusun kedalam matriks IE (Gambar 3.1).

Tabel 3.1 Penentuan Rating dan Skor Faktor-faktor Internal

\begin{tabular}{lccc}
\hline Faktor Penentu & Bobot & Rating & Skor \\
\hline Faktor Kekuatan & & & \\
\hline $\begin{array}{l}\text { Ikan patin memiliki kandungnan gizi dan omega 3 yang } \\
\text { tinggi, serta rendah kolesterol }\end{array}$ & 0,27 & 4,00 & 1,08 \\
$\begin{array}{l}\text { Desa Pering merupakan sentra penghasil ikan air tawar di } \\
\text { Bali }\end{array}$ & 0,27 & 4,00 & 1,08 \\
Usaha budidaya ikan dilakukan secara berkelompok & 0,03 & 3,00 & 0,08 \\
Ikan patin memiliki cita rasa yang gurih, dengan daging & & & \\
yang tebal & 0,14 & 4,00 & 0,54 \\
Sub Total & & & $\mathbf{2 , 7 8}$ \\
\hline Faktor Kelemahan & & & \\
\hline Biaya produksi tinggi & 0,14 & 2,00 & 0,27 \\
Rendahnya penerapan manajemen dan teknologi & 0,14 & 2,00 & 0,05 \\
Pemasaran kurang efisien & & & $\mathbf{0 , 7 3}$ \\
\hline Sub Total & & & $\mathbf{2 , 0 5}$ \\
\hline TOTAL
\end{tabular}

Analisis lingkungan eksternal usaha budidaya ikan patin merupakan identifikasi faktor-faktor peluang dan ancaman yang berada di luar kendali perusahaan, namun dapat memberikan pengaruh pada kinerja usaha peternakan. Keberhasilan perusahaan terletak pada kemampuannya mengadaptasi dan beradaptasi dalam lingkungan yang selalu berubah, hal ini mempengaruhi strategi usaha untuk menentukan bagaimana cara serta kapan saat yang tepat untuk bertahan dan berkembang. Faktor-faktor tersebut kemudian dinilai bobot dan skornya (Tabel 3.2), selanjutnya akan disusun kedalam matriks IE (Gambar 3.1).

Tabel 3.2 Penentuan Rating dan Skor Faktor-faktor Eksternal

\begin{tabular}{lcrr}
\hline Faktor Penentu & Bobot & Rating & Skor \\
\hline Peluang & & & \\
\hline $\begin{array}{l}\text { Gaya hidup masyarakat yang mengutamakan konsumsi } \\
\text { pangan bergizi }\end{array}$ & 0,35 & 3,00 & 1,05 \\
Benih ikan patin mudah diperoleh & 0,20 & 3,00 & 0,60
\end{tabular}


Tingginya perhatian pemerintah dalam pengembangan budidaya ikan air tawar di Kabupaten Gianyar

$0,35 \quad 4,00$
1,40

\begin{tabular}{llll}
\hline Sub Total & & & $\mathbf{3 , 0 5}$ \\
\hline Ancaman & & & \\
\hline Ikan patin belum dikenal luas di masyarakat & 0,05 & 1,00 & 0,05 \\
Tingginya harga pakan ikan berkualitas & 0,05 & 1,00 & 0,05 \\
\hline Sub Total & & & $\mathbf{0 , 1 0}$ \\
\hline TOTAL & & & $\mathbf{2 , 9 5}$ \\
\hline
\end{tabular}

Hasil analisis faktor internal dan eksternal yang telah diperoleh, selanjutnya dimasukkan kedalam matriks IE (Gambar 3.2) untuk menentukan posisi usaha budidaya ikan patin di Kecamatan Blahbatuh.

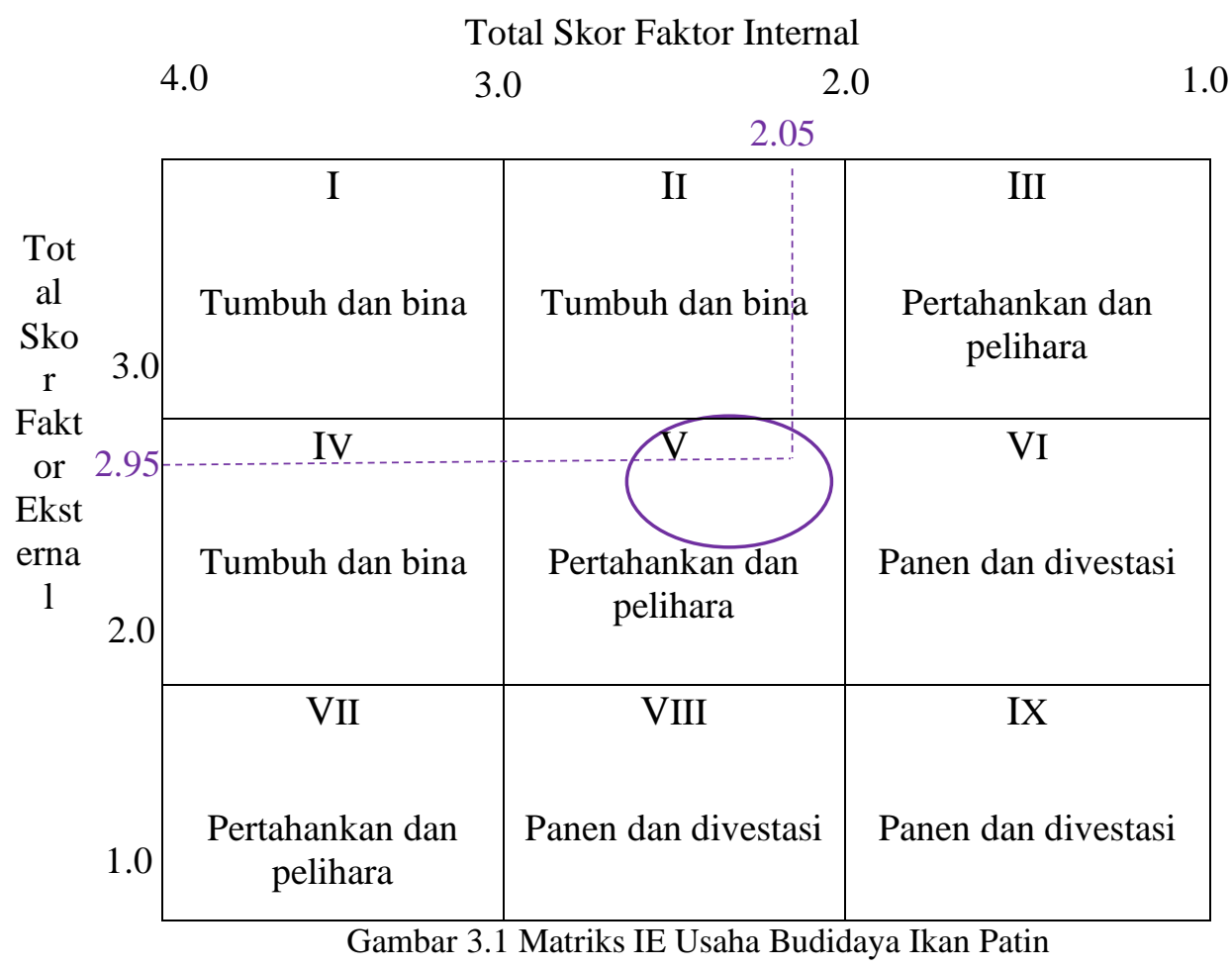

Usaha budidaya ikan patin yang ada di Kecamatan Blahbatuh berada pada sel kelima di dalam matriks IE dengan total skor IFE sebesar 2,05 dan total skor EFE sebesar 2,95. Sel kelima pada matriks IE menunjukkan bahwa usaha budidaya ikan patin memiliki daya tarik industri yang sedang, dengan kekuatan internal yang sedang. Untuk mendukung upaya pengembangan usaha budidaya ikan patin di Kecamatan Blahbatuh, maka perlu disusun alternatif strategi yang tepat, yaitu penetrasi pasar dan pengembangan produk (David, 2002).

\subsection{Alternatif Strategi}

Berdasarkan hasil analisis SWOT yang telah dilakukan, maka dapat dirumuskan alternatif strategi pengembangan usaha budidaya ikan patin sebagai berikut:

1. Melakukan integrasi usaha dari hulu hingga ke hilir

Untuk meningkatkan efisiensi usaha budidaya ikan patin serta meningkatkan pendapatan usaha, maka petani ikan perlu melakukan budidaya secara terintegrasi dari hulu hingga ke hilir dengan menerapkan empat prinsip utama yaitu: zero waste, social inclusiveness, multi product, serta 
inovasi dan adaptasi. Penerapan keempat prinsip ini dapat memberikan berbagai keuntungan bagi petani ikan baik secara ekonomi maupun lingkungan, yaitu 1) meningktakan nilai tambah produk, 2) ramah lingkungan, 3) efisiensi pemanfaatan sumberdaya dengan menerapkan teknologi yang adaptif, 4) terciptanya produk turunan yang memiliki nilai tambah yang lebih tinggi, dan 5) menciptakan peluang usaha baru bagi masyarakat sekitarnya.

2. Melakukan segmentasi pasar

Ikan patin, merupakan ikan air tawar yang meimiliki kandungan protein tinggi yaitu 12,94 $17,52 \%$, serta kandungan lemak yang rata-rata lebih rendah dibandingkan dengan ikan air tawar lainnya, yaitu berkisar anatar 0,89-1,23\% dengan kandungan lemak tak jenuh mencapai 50\% (Suryaningrum et al, 2010). Kandungan asam lemak essensial DHA pada ikan patinmencapai 4,74\% dan andungan EPA mencapai 0,31\%. Kandungan asam lemak omega-3 yang tinggi ini membuat ikan patin memiliki keunggulan dibandingkan dengan ikan air tawar lainnya. JIka dilihat dari tingginya kandungan gizi yang dimiliki ikan patin, maka sangatlah wajar jika ikan patin dijual dengan harga yang lebih tinggi dibandingkan dengan ikan air tawar lainnya.

Untuk dapat diterima dengan baik oleh konsumen, maka segmentasi ataupun pengelompokan pasar menjadi kelompok-kelompok kecil yang memiliki minat dan keinginan yang sama, sangat penting untuk dilakukan (Putri, 2017). Segmen pasar yang tepat bagi pemasaran ikan patin adalah kelompok masyarakat yang perduli terhadap kesehatan, dan mengutamakan konsumsi pangan yang memiliki kualitas dan gizi yang baik.

3. Mengadakan kerjasama dengan berbagai pihak dalam memasarkan patin dan produk olahannya Masyarakat di Provinsi Bali balum mengenal ikan patin dengan baik, dari segi kualitas, cita rasa, mapun cara pengolahannya. Untuk dapat memaski pasar dengan baik, maka petani ikan perlu melakukan kerjasama dengan pihak pemerintah untuk memperkenalkan manfaat mengkonsumsi ikan patin ke masyarakat, maupun kerjasama dengan pihak swasta dalam aplikasi pemanfaatan ikan patin sebagai bahan pangan bergizi, maupun sebagai bahan baku industri lainnya.

4. Memanfaatkan media online untuk promosi dan pemasaran produk Di era disrupsi saat ini, media online memiliki peranan yang sangat penting baik untuk menyebarluaskan suatu informasi maupun dalam mempromosikan produk baru.

5. Melakukan diversifikasi produk menjadi abon, nugget, ataupun bakso ikan patin

Diversifikasi produk menjadi berbagai jenis produk olahan, selain mampu memberikan nilai tambah yang lebih tinggi, dapat meningkatkan uur simpan, juga mampu meningkatkan pangsa pasar sehingga daya serap pasar tehadap produk olahan ikan patin menjadi lebih tinggi.

\subsection{Rekomendasi Strategi}

Berdasarkan analisis QSPM yang memperhitungkan nilai daya tarik masing-masing alternatif strategi, maka dihasilkan peringkat prioritas kemenarikan alternatif strategi sebagai berikut: 1) melakukan integrasi usaha dari hulu hingga ke hilir; 2) melakukan segmentasi pasar; 3) mengadakan kerjasama dengan berbagai pihak dalam memasarkan patin dan produk olahannya; 4) melakukan diversifikasi produk menjadi berbagai produk olahan lainnya; dan 5) memanfaatkan media online untuk promosi dan pemasaran produk;

Strategi melakukan integrasi usaha dari hulu hingga ke hilir ditetapkan sebagai strategi prioritas dalam pengembangan usaha budidaya ikan patin di Kecamatan Blahbatuh, dengan nilai TAS 4,82.

\section{UCAPAN TERIMA KASIH}


Ucapan terima kasih disampaikan kepada Dirjen Ristekdikti, Rektor Universitas Udayana, dan Ketua LPPM Universitas Udayana, atas bantuan dana yang telah diberikan. Ucapan terima kasih juga kami sampaikan kepada Pemerintah Daerah Kabupaten Gianyar, atas bantuan fasilitas, informasi dan kerjasama yang baik. Kepada Kelompok Tani Ikan Mina Kencana di Desa Pering, Kecamatan Blahbatuh, kami ucapakan terima kasih atas kerjasama yang sangan baik dalam mendukung kegiatan PKW Desa Pering dan Saba di Kecamatan Blahbatuh. Ucapan terima kasih juga kami sampaikan kepada berbagai pihak yang telah membantu kelancaran kegiatan ini.

\section{DAFTAR PUSTAKA}

David, F.R. 2002. Manajemen Strategis (Konsep). Edisi Ketujuh. Prenhallindo, Jakarta.

Kinnear,T.C and Tylor, J.R. 1996. Marketing Research: an applied Approach. $5^{\text {th }}$ Eddition. McGrawHill,Inc, New York.

Kotler, P. 1997. Manajemen Pemasaran. Jilid 1 dan 2. Penerbit Prenhallindo, Jakarta

BPS Kabupaten Gianyar. 2018. Kabupaten Gianyar Dalam Angka. Badan Pusat Statistik Kabupaten Gianyar, Bali.

Putri,B.R.T. 2017. Manajemen Pemasaran Produk Peternakan. Swasta Nulus, Denpasar.

Sardiana, IK., BRT Putri, IG Suranjaya, NLR Purnawan. 2015. Pengembangan Kewirausahaan di Universitas Udayana. Ngayah: Majalah Aplikasi IPTEKS 6 (1)

Suryaningrum, T.D., Miljanah, I., dan Tahapari,E. 2010. Profil Sensori dan Nilai Gizi Beberapa Jenis Ikan Patin dan Hibrid Nasutus. Jurnal Pascapanen dan Bioteknologi Kelautan dan Perikanan. Vol 5 (2) Desember 2010. 